\title{
IL7 wt Allele
}

National Cancer Institute

\section{Source}

National Cancer Institute. IL7 wt Allele. NCI Thesaurus. Code C50941.

Human IL7 wild-type allele is located within 8q12-q13 and is approximately $73 \mathrm{~kb}$ in length. This allele, which encodes interleukin-7 protein, plays a role in both $V(D) J$ recombination during early $T$ cell development and lymphoid cell survival. 